Trinity University

Digital Commons@ Trinity

Biology Faculty Research

Biology Department

2013

\title{
Community and Ecosystem Effects of Buffelgrass (Pennisetum ciliare) and Nitrogen Deposition in the Sonoran Desert
}

Kelly G. Lyons

TrinityUniversity, klyons@trinity.edu

B. G. Maldonado-Leal

G. Owen

Follow this and additional works at: https://digitalcommons.trinity.edu/bio_faculty

Part of the Biology Commons

\section{Repository Citation}

Lyons, K.G., Maldonado-Leal, B.G., Owen, G. (2013). Community and ecosystem impacts of buffelgrass (Pennisetum ciliare) and nitrogen addition in the Sonoran Desert. Invasive Plant Science and Management, 6(1), 65-78. doi: 10.1614/IPSM-D-11-00071.1

This Post-Print is brought to you for free and open access by the Biology Department at Digital Commons @ Trinity. It has been accepted for inclusion in Biology Faculty Research by an authorized administrator of Digital Commons @ Trinity. For more information, please contact jcostanz@trinity.edu. 


\title{
Community and Ecosystem Effects of Buffelgrass (Pennisetum ciliare) and Nitrogen Deposition in the Sonoran Desert
}

\author{
K.G. Lyons, B.G. Maldonado-Leal, and G. Owen* \\ First author: Associate Professor, Trinity University, Dept. of Biology, One Trinity Place, San \\ Antonio, TX 78212, USA; klyons@ @trinity.edu.; Second author: Chief, Departamento de Manejo \\ de Combustibles, Gerencia de Protección Contra Incendios Forestales, Coordinación General de \\ Conservación y Restauración, Comisión Nacional Forestal, Periférico Poniente No. 5360, Col. \\ San Juan de Ocotán, Zapopan, Jalisco, MEX, Edificio “C” C.P. 045019; \\ bmaldonado@conafor.gob.mx; Third author: Research Social Scientist, Climate Assessment for \\ the Southwest, University of Arizona, P.O. Box 210156, Tucson, AZ 85721, USA; \\ gigi@email.arizona.edu.
}

Buffelgrass is a non-indigenous, invasive, $\mathrm{C} 4$ grass was introduced throughout much of southern Texas, the Southwestern United States, and northern and central Mexico to improve degraded rangelands. The successful introduction and spread of buffelgrass follows a trajectory similar to that of other invasive C4 grasses in arid and semiarid ecosystems. In the Plains of Sonora of the Sonoran Desert (Mexico) buffelgrass is favored by widespread removal of native vegetation and seeding, but, why, following initial introduction, the species persists at the expense of the native herbaceous species remains unclear. In this study, we addressed two concerns associated with buffelgrass invasion in the Plains of Sonora. We hypothesized that under arid rangeland conditions buffelgrass outcompetes native herbaceous species 1) through rapid acquisition of limiting nutrients (here assumed to be nitrogen) and 2) under conditions with high nitrogen input. 
In summer 2002, a 2x2 factorial experiment was established with buffelgrass removal and nitrogen addition in both intact desert and converted buffelgrass grassland habitats. In winter 2003, we found that, regardless of habitat type, buffelgrass removal had a positive effect on abundance, biomass, and richness of native herbaceous species while addition of nitrogen, as urea (at $50 \mathrm{~kg} \mathrm{~N} / \mathrm{ha} / \mathrm{yr}$ ), and disturbance resulted in reduction in abundance and biomass. Nitrogen addition did not negatively alter buffelgrass cover. Nitrogen addition had the expected result of increasing initial, peak and total NO3 and NH4 mineralization with the exception of NO3 measures in intact desert. Removal of buffelgrass did not result in significant increases in soil NO3 or NH4 with the exception of peak NH4 in intact desert. Results of this study support observations that native herbaceous species are displaced by buffelgrass invasion and that nitrogen pollution will likely favor buffelgrass over the native herbaceous species in this ecosystem.

Nomenclature: buffelgrass, Pennisetum ciliare (L.) Link (Poaceae), formerly Cenchrus ciliaris L.

Key Words: Plains of Sonora; Mexico; desert grasslands; arid ecosystems, conversion

\section{Interpretive Summary:}

Buffelgrass is extensively planted in arid and semi-arid grassland ecosystems across the planet and has been useful in stabilizing soils and increasing productivity in rangelands where there has been widespread drought combined with overgrazing. Nonetheless, grassland conversion to accommodate buffelgrass plantings and invasion of the species itself has caused widespread and extreme collateral damage. In this study, we confirm that buffelgrass displaces native species. The study also demonstrates that high levels of nitrogen addition in low rainfall years results in neutral effects on buffelgrass and significantly negative effects on native herbaceous species. 
Given buffelgrass' significant negative impacts on biodiversity, its ability to alter fire regimes and establish a positive feedback loop, and its threat to the existence of ecosystems that have aesthetic and economic value in business sectors other than ranching (e.g., tourism in Arizona, U.S.A.), management of these rangelands for buffelgrass control is recommended as a high priority. Managers introducing buffelgrass to improve rangelands should take into consideration the species negative impacts on native forb and grass diversity, habitat for mammals and grounddwelling birds, and the probable irreversible alteration of the ecosystem. In areas of conservation concern where biodiversity is a management goal we advocate 1 . rigorous vigilance and immediate removal of nascent foci, 2. where established, an aggressive removal campaign (without the use of fire), and 3. outreach to increase public awareness about the negative effects of the species, and 4. where possible, reduced exposure to atmospheric nitrogen deposition.

The worldwide use of non-indigenous $\mathrm{C} 4$ grasses for rangeland improvement in arid ecosystems has increased substantially in the last 60 years. African grasses are highly opportunistic, making large allocations to biomass when water is available. They are also highly 
drought tolerant, ceasing growth and senescing when water is scarce (Williams and Baruch 2000 and references therein). In addition, non-indigenous $\mathrm{C} 4$ grasses are demonstrated to have high maximum photosynthetic rates and higher maximum stomatal conductance, and photosynthetic and transpiration rates than native C4 grasses (Baruch 1996, Baruch et al. 1985, Baruch and Fernandez 1993, Simoes and Baruch 1991).

During the early 1900s, overgrazing of arid rangelands throughout northern Mexico and the Southwestern United States resulted in widespread decline of native perennial grass productivity, forcing ranchers to reduce stocking rates (Bahre 1995, Bryan 1925, Cox et al. 1983). In the search for grasses to improve rangeland productivity, strains of buffelgrass (Pennisetum ciliare (L.) Link, a.k.a. zacate buffel), a perennial, C4 grass native to Africa (Christie 1975, Cox et al. 1988, Williams and Baruch 2000), were brought to the United States as early as 1889 (Van Devender et al. 2009). Buffelgrass was introduced to arid rangeland ecosystems from 1902 through the early 1940s (Brenner 2011, Cox et al. 1984) by USDA Division of Agrostology and the ARS, Texas Agricultural Extension Service, Soil Conservation Service and the commercial seed industry (Brenner 2011, Cox 1999). In 1988, Hanselka estimated that buffelgrass was growing on more than 1.7 million acres in the state of Texas. Current estimates are as high as 5 million acres (John Lloyd-Reilley, "Kika" de la Garza Plant Materials Center, personal communication). In southern Arizona buffelgrass is mostly found along roadside rights-of-way but is spreading rapidly into native vegetation. This is a large concern for conservation of the iconic paloverde-saguaro communities, upon which so much of southern Arizona's tourism depends.

It is estimated that Buffelgrass was first introduced in north Mexico in the states of Nuevo Leon and Tamaulipas and later to the state of Sonora (Brenner 2011, Miranda et al. 
1999). The intensity of introduction of buffelgrass in Sonora increased in the 1970s (Cox et al.1984, Ibarra-F. et al. 1987, Ibarra-F. et al. 2009) and the species is still actively seeded today (K. Lyons, personal observation). By 1991, 1.4 million hectares of land in Mexico had been converted to buffelgrass grassland with approximately 300,000 of those hectares in the state of Sonora (Ibarra-F. et al. 1991). In 1992, this estimate had increased to 400,000 hectares (Johnson and Navarro 1992). Búrquez-M. et al. (2002) suggest that, through a combination of legal and illegal activities, as much as 1.6 million hectares of land have been cleared and seeded with buffelgrass in the state of Sonora, although the official SEMARNAT estimate in 2006 was approximately one million hectares. Using Landsat images, Franklin et al. (2006) calculated that Buffelgrass conversion in a 1,850,000 ha area centered on Hermosillo, Sonora, Mexico increased from 7700 ha in 1973 to 140,000 ha in 2000 , an amount that constitutes $8 \%$ of the land surface surveyed.

The introduction of invasive $\mathrm{C} 4$ grasses and accompanying grassland conversion methods have significant impact on ecosystem function and stability. Their introduction results in alteration of mineralization rates, nutrient and hydrologic cycles, and disturbance regimes, in particular those involving fire (D'Antonio and Vitousek 1992, Esque et al. 2006, Williams and Baruch 2000). Due to its massive root system, buffelgrass is able to withstand fires and respond more quickly than other herbaceous desert species. The species is often referred to as a bunchgrass, however, while most bunchgrasses die back to the root crown during drought and freezing temperatures and then regrow stems and leaves before flowering, buffelgrass dies back only to short stems with nodes, leaving viable apical meristems at the soil surface. This allows the species to grow new leaves and flowers quickly when the climate improves. Buffelgrass may therefore be more appropriately referred to as a subshrubby 'chamaephytic' grass ( $\mathrm{T}$. 
VanDevender, personal communication). Furthermore, buffelgrass' high productivity results in larger, more continuous fuel loads that are no longer isolated to tree/shrub/cacti complexes. As a result, fires now carry through desert ecosystems and threaten species that are poorly adapted to frequent fires, such as the saguaro and pitayo cacti. Thus, in the U.S. desert Southwest and Northern Mexico buffelgrass acts as an ecosystem engineer, causing a fire feedback loop and "grasslandification" of desert and thornscrub habitats.

Until very recently, conversion of desert or thornscrub vegetation to buffelgrass pastures in the Plains of Sonora in Mexico was generally accompanied by complete or partial removal of the native woody vegetation by bulldozing or chaining, a process referred to as desmonte. As a result, substantial tracks of land are now either dominated by buffelgrass, where cattle can be adequately rotated, or highly degraded with little vegetation, where overgrazing occurs (K. Lyons, personal observation). Due to the slow growing nature of the species in this system, there is little hope of return or restoration of the diverse woody growth forms. An equally alarming consequence of these conversions, and despite efforts to maintain some intact desert, is a ubiquitous spread of buffelgrass into native, intact desert or thornscrub (de la Barrera 2008). In flat terrain of the Plains of Sonora, establishment of buffelgrass in intact desertscrub generally begins under tree-shrub complexes, which serve as islands of biodiversity, and spreads into open habitat through time. The species invasion appears to be positively facilitated by previously established buffelgrass individuals as well as disturbance by small mammals and lizards (K. Lyons, personal observation). On rocky hillsides, alongside native cacti and woody shrubs, buffelgrass effectively fills the spaces between rocks.

Due to its high abundance beneath shrubs and trees, rapid spread into open habitat, and propensity to burn, buffelgrass is assumed to have large consequences on native species 
abundance. Nonetheless, only a handful of studies have been conducted on these impacts in arid and desert ecosystems. In a post-establishment observational study, buffelgrass abundance has been negatively correlated with native, herbaceous species cover, abundance, and diversity (Búrquez-M. et al. 2002, Sands et al. 2009, Olsson et al. 2012, as well as Abella et al. in review/in press with IPSM). Not surprising, where buffelgrass establishment is accompanied by grassland conversion, woody species are found to be negatively correlated buffelgrass invasion. Indeed, conversion of intact desert to buffelgrass grasslands results in a $50 \%$ reduction in richness of all perennial plant species and a 78\% reduction in trees and shrubs (Franklin and Molina-F 2010). A number of studies have also shown the negative effects of buffelgrass invasion and grassland conversion on native animals (Bestelmeyer and Schooley 1999, Flanders et al. 2006, Smyth 2009). These results underscore a conflict between widespread clearing of woody species in larger ranching operations and consensus among many ranchers in the state of Sonora, Mexico that intact, native desert scrub vegetation is of high forage value due to its diversity, drought tolerance and staggered productivity (Brenner 2011).

Several manipulative studies provide support for the negative effects of grassland conversion and/or buffelgrass introduction on native species abundance. In a neighborhood transplant study designed to assess the relative competitiveness of two invasive, non-indigenous grasses, buffelgrass and natal grass (Melinis repens), Stevens and Fehmi (2009) found that buffelgrass had a higher potential to displace the Sonoran Desert native grass Arizona cottontop (Digitaria californica). Likewise, removal of buffelgrass using herbicides in a south Texas grassland resulted in increases in native grass cover (Tjelmeland et al. 2008). Finally, in a study comparing thornscrub and converted buffelgrass pasture Morales-R and Molina-F (2008) found 
that seedlings of a dominant columnar cactus (Pachycereus pecten-aboriginum) successfully regenerated in thornscrub but died in converted pasture.

The removal of desert or scrub vegetation combined with grassland conversion using buffelgrass has been shown to also have significant effects on arid ecosystem soils and soil dynamics. In the arid northwest of Mexico, Ibarra-F. et al. (1995) assessed the survival of USDA T-4464 buffelgrass as a function of climatic and soil characteristics. Buffelgrass success was determined by categorization into one of three categories: spreads, persists or dies. Total organic and nitrogen levels were lowest where the buffelgrass was spreading, intermediate where the species persisted, and highest where the species died. These results suggest that buffelgrass tolerates and/or creates low nutrient soil conditions and holds soil nutrients in its tissues. In a later study, using paired plots comparing buffelgrass-dominated and "virgin" grassland, Ibarra-F et al. (1999) assessed the effects of buffelgrass on soil chemistry in three regions of Mexico to include two arid ecosystems in the northwest and northeast and a tropical region in the southeast. The results of their study indicate that buffelgrass establishment had significant negative effects on soil organic carbon and nitrogen in the southeast and magnesium in the northwest and marginally significant reductions in soil organic carbon and nitrogen in the northwest. These results suggest that buffelgrass has large impacts on soil nutrients in the tropics but limited impacts in arid ecosystems.

The presence of persistent homogenous buffelgrass grasslands in cleared portions of the Sonoran Desert combined with low soil nutrient levels in these grasslands suggest that buffelgrass is an effective competitor for limiting nutrients and outcompetes native species. But what is the nature of this competitive dynamic under higher levels of atmospheric nitrogen deposition? Agriculturalists concerned with declining buffelgrass grassland productivity over time have found 
that nitrogen inputs substantially increase buffelgrass productivity (e.g., Peake et al. 1990); however, in these types of studies collateral effects on native species are often not reported. Increases in soil nitrogen deposition are often positively correlated with non-indigenous and indigenous invasive species fitness, establishment and spread (Abraham et al. 2009, Bell and Treshow 2002, Burke and Grime 1996, Hobbs et al. 1988, Metcalfe and Fowler 1998, SchererLorenzen et al. 2000, Vasquez 2008, Wedin and Tilman 1996, McLendon and Redente 1991, Melgoza and Nowak 1991, Kolb et al. 2002, Brooks 2003, Norton et al. 2007, Vasquez 2008 and references therein, MacKown et al. 2009, James et al. 2011 and references therein).

Furthermore, systems dominated by $\mathrm{C} 4$ grasses generally have lower species richness and higher productivity in response to nitrogen addition (Clark et al. 2007).

Work conducted on buffelgrass invasion in the Sonoran Desert has focused on the effects of ecosystem conversion on buffelgrass grasslands but the effect of buffelgrass competition, per se, on native species and soil resources remains poorly studied. This is due to the fact that soil resource status and native species abundance are dictated by factors that are easily confounded such as the degree of establishment of buffelgrass, variability in soil biogeochemistry, land-use history, and disturbance cycles. It is therefore important to conduct manipulative studies to determine the mechanisms driving the patterns we find in soil resources and species composition.

In this study, we aimed to determine the effects of buffelgrass on the desertscrub ecosystem more directly through a manipulative approach. The experiment was designed specifically to test the effect of buffelgrass and nitrogen, alone and in combination, on ecosystem processes and native herbaceous species abundance. We were also interested in the effects of nitrogen deposition (pollution) on native species and buffelgrass. We therefore included a soil nitrogen addition treatment. Finally, we aimed to separate the effects of grassland conversion from those of 
buffelgrass introduction and spread. Because buffelgrass has been introduced in converted desert and has spread into intact desertscrub, we tested the effects of our treatments in both habitat types. We focused on the following questions:

1. What is the impact of grassland conversion on native herbaceous species abundance?

2. What is the impact of buffelgrass invasion on native herbaceous species abundance?

3. What is the nature of competition for nitrogen between native species and buffelgrass?

4. What is the effect of high levels of nitrogen on the competitive dynamics between buffelgrass and native herbaceous species?

Our study focused on native species of the Plains of Sonora subdivision (Shreve and Wiggins 1964) where a majority of conversion of the Sonoran Desert to buffelgrass grassland has occurred (Búrquez-M. et al. 2002). The experiment was conducted between July 2002 and March 2004. The treatments consisted of buffelgrass removal in July 2002, a follow-up removal in December 2002, and seasonal additions of nitrogen prior to onset of summer and winter rainfall events. Here we report on results of the winter 2003 rainy season.

\section{Materials and Methods}

Experimental Site. The site chosen for this study is north of Hermosillo, Sonora, Mexico near the city of Carbó $\left(29^{\circ} 31^{\prime} \mathrm{N}, 111^{\circ} 03^{\prime} \mathrm{W}\right)$, on land belonging to the Patronato del Centro de Investigaciones Pecuarias del Estado de Sonora (PATROCIPES), a rancher's association of Hermosillo, Sonora (Ibarra et al. 2009). The woody plant community is dominated by the 
leguminous trees Olneya tesota (ironwood) and Prosopis velutina (velvet mesquite) and Stenocereus thurberi (organ pipe) and Lophocereus schottii (senita) cacti. The dominant shrubs in this community include the legumes Caesalpinia palmeri (palo piojo), Calliandra eriophylla (fairy duster), Desmanthus covillei (bundleflower), Eysenhardtia orthocarpa (kidneywood), and Mimosa distachya var. laxiflora (catclaw mimosa), and the euphorbs Croton sonorae (Sonoran croton) and Jatropha cardiophylla (limberbush). Dominant winter herbaceous species include the annual (Bouteloua aristidoides, B. barbata) and perennial (Cathestecum brevifolium) grasses, and forbs such as Ipomoea ternifolia var. leptotoma (morning glory), Portulaca suffrutescens (copper purslane) and Euphorbia florida (golondrina). Approximately 25 year ago PATROCIPES converted approximately 18,000 of their 33,000 hectares to buffelgrass grassland through bulldozing and seeding (Lic. Alfonso Elías-Serrano, PATROCIPES, personal communication). The buffelgrass grasslands have been managed using a traditional cattle rotation scheme. These grasslands are in unusually good health compared to other buffelgrass grasslands of the Plains of Sonora, which is generally attributed to the large size of the ranch that allows consistent rotation of the cattle to avoid overgrazing (Manuel Fontes, PATROCIPES, personal communication).

In late June 2002, before onset of the summer rains, an experimental site of ca. two hectares was established approximately eight kilometers from the highway. The site was placed well away from the highway to minimize the threat of fire. In addition, the experimental site was chosen to avoid cattle watering locations where soil nitrogen might be concentrated. The study area spanned adjacent, representative habitat of desert that was converted to buffelgrass grassland (converted desert, CD) and intact desertscrub (intact desert, ID) vegetation. The difference between these two habitats is evident due to the extensive bulldozing and homogenous 
growth of buffelgrass in areas converted to grassland. Over the course of the investigation we noted gray bark on some shrubs in the ID habitat indicating that the area may have been subjected to fire at some point in the past. None of the ranch hands were familiar with any recent fires (over the previous 20 years) and the large trees and shrubs, ocotillo, and cacti were wholly intact, differing in no way from the surrounding ID vegetation. Figure 1 demonstrates graphically how these sites differ in vegetation. Buffelgrass grasslands have lower values for all plant growth forms with the exception of native grasses. In addition, these areas are clearly divided by narrow windrows of shrub vegetation called "chorizos", a term referring to sausagelike windrows. On August 14-15, 2002 the experimental plot was fenced to exclude cattle. A weather station with a rain gauge and temperature and relative humidity sensors (HOBO Data Loggers, Onset Computer Corp.) was erected. Rainfall data was collected continuously and downloaded approximately every two weeks. Temperature and relative humidity data was recorded every 15 minutes and downloaded also approximately every two weeks.

Experimental Design. Treatments consisted of manipulations of buffelgrass removal and nitrogen addition in a $2 \times 2$ factorial design, plus experimental and procedural controls. A randomized complete block design was employed with the following treatments: 1. control (C), 2. buffelgrass removal (-B), 3. nitrogen addition $(+N)$, 4. buffelgrass removal combined with nitrogen addition $(-\mathrm{B}+\mathrm{N}), 5$. a procedural control for the disturbance created by buffelgrass removal (-Bc), and 6. a control for disturbance plus nitrogen addition $(-\mathrm{Bc}+\mathrm{N})$. The experiment consists of four blocks in ID and three blocks in CD. Fewer blocks were established in the converted desert grassland due to apparent high homogeneity. Each block includes six adjacent treatment plots measuring $5 \times 25 \mathrm{~m}$ and separated by $1.5 \mathrm{~m}$. 
In -B treatments, buffelgrass was removed by shovel and hand weeding and moved out of the plots. For the purpose of this experiment discreet tussocks were assumed to be buffelgrass "individuals." Disturbance control treatments for buffelgrass removal (-Bc) were applied by digging holes equivalent to an estimated average number and size of disturbance of the two buffelgrass removal treatments within a block. Through this procedural control we aimed to account for the effects of disturbance, per se, on native species and soil processes such as disturbance to soil microbial growth or nutrient cycling. Another confounding factor for which we did not control was the decomposition of root fragments left behind after buffelgrass removal. Before any removal occurred, the number of buffelgrass individuals under tree/shrub complexes and in open desertscrub matrix were counted in the $-\mathrm{B}$ and $-\mathrm{B}+\mathrm{N}$ plots. The average size among disturbances created by the removal of buffelgrass tussock was determined by measuring the length, width and central depth for 20 soil disturbance areas randomly selected among the $-\mathrm{B}$ treatments within a block. Average numbers of disturbances under tree/shrub complexes and in open habitat was calculated for the two treatments with buffelgrass removal within a block. These estimates were then used to create an average number of randomly placed soil disturbances of the approximate average size and type (open or under tree/shrub complexes) in $-\mathrm{Bc}$ treatments within a given block. Follow-up removals were performed prior to the onset of the 2003 winter rains and control for the removal was again conducted to match the disturbance created in the second round of removal.

On July 25 and December 30, 2002, following the first substantial rain and germination of the first winter annuals, nitrogen was added to entire $5 \times 25$ treatment plots in granular form as $\mathrm{N}-\mathrm{NH}_{4}$ at a rate of $5 \mathrm{~g} \mathrm{~N} / \mathrm{m}^{2}$ (or $50 \mathrm{~N} \mathrm{~kg} / \mathrm{ha}$ ). Applying nitrogen post-germination was done to ensure nutrient uptake and avoid leaching (Eviner et al. 2000). 


\section{Response Variables.}

Plant Abundance. To assess the effect of our experimental treatments on native species and buffelgrass productivity, measures of abundance were made at peak productivity during the 2002-2003 winter rainy season. Data were collected February 12-27, 2003 from a 25 m transect longitudinally bisecting the $5 \times 25 \mathrm{~m}$ treatment plot. The transect was divided into 20 contiguous $1 \times 1 \mathrm{~m}$ plot and data collection occurred on both sides of the transect between 2 and $22 \mathrm{~m}$ for a total of $40,1 \mathrm{~m}^{2}$ subplots. To allow room to work with minimum disturbance to the plots, the edge of each $1 \mathrm{~m}^{2}$ plot parallel to the transect was placed $0.5 \mathrm{~m}$ away from the transect. Percent cover was assessed for the following: buffelgrass, native woody and herbaceous species, standing dead wood, herbaceous litter, total bare ground and bare ground consisting of nothing, cattle trails or cryptobiotic crust. We also assessed the percent cover of disturbed soil and whether this disturbance resulted from our soil extractions (see below) or animal activity. Native herbaceous species productivity and richness was further assessed through collection of biomass from $625 \mathrm{~m}^{2}(25 \times 25 \mathrm{~cm})$ plots at the outer edge of ten $1 \times 1 \mathrm{~m}$ cover collection plots. The biomass was sorted by species and bagged in the field and returned to the laboratory where it was dried to a constant weight and weighed.

Nitrogen Availability. Net nitrogen mineralization rates were determined using a modification of the resin core method (Binkley and Matson 1983), originally developed by DiStefano and Gholz (1986). For each treatment plot in CD and ID, three replicate collection locations were identified using stratified random sampling at regular intervals along the $25 \mathrm{~m}$ transect. Soil analysis involved three soil collections: an initial soil core; an incubated soil core plus resin bag; and a peak soil core. Nitrogen data was collected from only the four main experimental treatments $(\mathrm{C}$, $-\mathrm{B},+\mathrm{N},-\mathrm{B}+\mathrm{N})$. 
On January 5, 2003, initial soil samples measuring 7 x $12 \mathrm{~cm}$ (width $\mathrm{x}$ depth) were collected. Twelve centimeters is the estimated depth of the bulk of root biomass of the focal herbaceous species in this study, including buffelgrass. Less than $10 \mathrm{~cm}$ from the initial sample, a second soil core was extracted and placed in a 7 x $12 \mathrm{~cm}$ PVC cylinder with as little disturbance as possible; however, due to the sandy, dry character of the soils it was difficult to maintain the soil profile intact. Once secured in the tube, approximately $3 \mathrm{~cm}$ of the bottom of each soil core was removed and replaced with a $20.25 \mathrm{~cm}^{2}(4.5 \mathrm{~cm}$ x $4.5 \mathrm{~cm})$ resin bag containing a mixture of $3 \mathrm{~g}$ each of anion and cation exchangeable resins (Purolite A-400 (anion) and C-100E (cation)). The resin bag was then covered with approximately $2 \mathrm{~cm}$ of soil and the pvc tube, soil and resin bag combination was returned to the cored hole with the resin bag down and so that the top of the pvc tube was less than $0.5 \mathrm{~cm}$ above the soil surface. The soil resin cores plus a final $7 \times 12 \mathrm{~cm}$ sample, located $\sim 10 \mathrm{~cm}$ from the soil resin core, were collected at estimated peak biomass on February 28, 2003.

Upon collection, all soil samples were promptly placed in polyurethane bags, placed on ice in a cooler and moved as quickly as possible to a laboratory refrigerator. Soil extractions were conducted within 24 hours of collection. Nutrient extractions for soil and exchangeable resins were done using $2 \mathrm{M} \mathrm{KCl}$, following the protocols of Robertson et al. (1999). Solutions were analyzed for $\mathrm{NH}_{4}$ and $\mathrm{NO}_{3}$ using Continuous Flow Colorimetric Assay at the University of Georgia, Institute of Ecology, Stable Isotope Laboratory.

Statistical Analysis. Comparisons of differences in cover, richness, biomass and nitrogen measures between CD and ID were conducted using a SAS version 9.1 GLM Mixed Model (PROC MIXED) and Tukey least squares means post-hoc contrasts (SAS Institute, Cary, North Carolina, USA, 2004). Where necessary, cover, richness, biomass and nitrogen measures were 
log-transformed to meet assumptions of normality and homoscedasticity. The following factors were analyzed: buffelgrass removal (-B); nitrogen addition $(+\mathrm{N})$; buffelgrass removal by nitrogen $(-\mathrm{B}+\mathrm{N})$; block; and subplot nested within the crossed effects of buffelgrass removal, nitrogen addition, and block (i.e., subplot $\left(-\mathrm{B}^{*}+\mathrm{N}^{*}\right.$ block)) (Table 1). Block and nested subplot effects were treated as random factors. These random factors were consistently non-significant in both $\mathrm{CD}$ and ID for all nitrogen analyses and were therefore removed from the model.

\section{Results and Discussion}

GLM mixed-model analysis and treatment contrasts on buffelgrass cover demonstrate that our goal to reduce invader cover was successful in both CD and ID (Table 1, Fig. 2a, b). Comparison of control and buffelgrass removal treatments shows that, on average, buffelgrass cover was reduced from $35 \%$ to $7 \%$ and $15.8 \%$ to $0.43 \%$ in CD and ID, respectively. Removal of buffelgrass in ID was more effective presumably due to lower initial cover and higher buffelgrass recruitment limitation relative to $\mathrm{CD}$. Compared to the control treatment, neither nitrogen addition nor disturbance alone had an effect on buffelgrass cover in either ID or CD (Table 1, Fig. 2a, b).

Conversion from a shrub-dominated habitat to buffelgrass-dominated grassland is implicated in the widespread displacement and decline of native herbaceous species. In general native herbaceous species cover among treatments was higher in ID than in CD (Fig. 1, Fig. 2c, d). In both ID and CD, buffelgrass removal had an overall statistically significant positive effect 
on all measures of native species to include cover, biomass and richness (Table 2, Fig. 2c, d, e, f). The effects of the removal of buffelgrass suggests that the species is directly competing for resources (e.g., nutrients and/or space) with native herbaceous species and is likely displacing them when establishing and spreading into intact desertscrub.

Recruitment limitation is of great conservation concern in habitats that have been involved in intensive land use (Tilman 1997). Relative to the high diversity typically found among native herbaceous species in this ecosystem, we found relatively low levels of richness in this winter rainfall season (6 species on average in both CD and ID with typical ranges within a plot of 1-3 species) and the majority of the natives were early succession species. These data suggest that a select number of native herbaceous species are not yet catastrophically recruitment or seed-bank limited and, following removal of buffelgrass, can increase. Nonetheless, it remains unclear if the current seed bank has the capacity to restore native herbaceous species to early settlement levels or if it is limited to early succession ruderals. Further study of the potential of the seed bank is warranted.

Overall, addition of nitrogen significantly negatively affected native herbaceous species cover in both CD and ID and biomass in ID but had no effect on native herbaceous species richness (Table 2). Relative to controls, addition of nitrogen alone had no effect in CD (Fig. 2c) but significantly reduced cover of native herbaceous species in the ID (Fig. 2d). In contrast to buffelgrass removal alone, buffelgrass removal combined with nitrogen $(-\mathrm{B}+\mathrm{N})$ appeared to have had no effect on native herbaceous species cover, richness or biomass in CD or ID (Table 2); however, trends in the data demonstrate an intermediate effect between $-\mathrm{B}$ and $+\mathrm{N}$ (Fig. 2c, d, e, f), which we attribute to the opposing effects of these treatments. While the trend for the removal of buffelgrass with nitrogen addition is consistent between habitat types, it is 
significantly different from $\mathrm{C},-\mathrm{B}$, and $+\mathrm{N}$ and for cover in ID (Fig. 2d) and biomass in ID and $\mathrm{CD}$ (Fig. 2e, f). Thus, removal of buffelgrass results in an increase in native herbaceous species but nitrogen addition counteracts this effect.

Our study clearly demonstrates that high levels of nitrogen addition (50kg N/ha/yr) can cause significant declines in native herbaceous species abundance. In most ecosystems, nitrogen acts as a limiting resource for plant growth and it is widely accepted that nitrogen supplementation greatly increases crop yields. Nonetheless, there is a concentration threshold beyond which nitrogen deposition results in damage to plants. Investigations aimed at assessing nitrogen as fertilizer for improved plant growth or yield generally apply nitrogen in concentrations ranging from $<1$ to $25 \mathrm{~kg} \mathrm{~N} / \mathrm{ha} / \mathrm{yr}$ while studies focused on nitrogen deposition as pollution typically apply amounts exceeding $30 \mathrm{~kg} \mathrm{~N} / \mathrm{ha} / \mathrm{yr}$ (e.g., Egerton-Warburton et al. 2007 (100-150 kg N/ha/yr)). As might be expected, the latter concentrations correspond to measured pollution levels. In areas surrounding urban centers in southern California, USA, nitrogen deposition can be has high as $45 \mathrm{~kg} \mathrm{~N} / \mathrm{ha} / \mathrm{yr}$ (Bytnerowicz et al. 1987, Bytnerowicz and Fenn 1996, Fenn et al. 2003). Similarly, nitrogen deposition levels have been reported up to $40 \mathrm{~kg}$ N/ha/yr in parts of Sweden (Grennfeld and Hultbert 1986) and Mt. Mitchell State Park, North Carolina, USA (Aneja and Murthy 1994). At the extreme end, nitrogen pollution levels as high as $115 \mathrm{~kg} \mathrm{~N} / \mathrm{ha} / \mathrm{yr}$ have been reported in the Netherlands (Draijers et al. 1989).

The role of nitrogen addition as a determinant of the competitive dynamics between resident and invasive species remains elusive but some trends are emerging. A number of investigators have found trends similar to those in our study where nitrogen addition reduced growth of native species and either enhanced or had no effect on non-indigenous, invasive species. In the western United States increases in growth of non-indigenous, annual grasses at 
the expense of native, perennial grasses is widely attributed to increases in nitrogen (see reviews by James et al. 2011 and Vasquez 2008). These trends are often found at relatively low levels of nitrogen supplementation; among the studies included in the review conducted by James et al. (2011) no nitrogen addition treatments exceeded $1 \mathrm{~kg} \mathrm{~N} / \mathrm{ha} / \mathrm{yr}$.

In contrast, some studies demonstrate that native, perennial grasses are competitive with invasive, annual grasses where nitrogen is supplemented. In what was considered a fertilizer study in the Mojave Desert, USA (Joshua Tree), Rao and Allen (2010) found that $30 \mathrm{~kg} \mathrm{~N} / \mathrm{ha} / \mathrm{yr}$ enhanced both native and non-indigenous invasive species, although the non-indigenous species was more responsive. At this same nitrogen concentration, Seabloom et al. (2003) found no differences in establishment between native, perennial grasses and non-indigenous, annual grasses. Likewise, McGlone et al. (2012) found that native, perennial grasses were able to outcompete non-indigenous, annual grasses under all growth conditions to include supplemental water, nitrogen and phosphorus.

The mechanism of damage caused by high nitrogen deposition appears to be ecosystem and plant and microbe species dependent (e.g., Egerton-Warburton 2007). Furthermore, at higher levels of nitrogen addition soil microbial relationships become more complicated. We suggest four possible mechanisms for why in our study nitrogen addition resulted in declines in measures of abundance of native, herbaceous species. Nitrogen addition as urea 1) results in changes in soil chemistry that negatively affect plant tissues or nutrient uptake processes (e.g., changes in soil $\mathrm{pH}$, accumulation of ammonia or nitrite, denaturing enzymes), 2) increases soil microbial activity creating a more competitive environment for soil nutrients wherein buffelgrass is a better competitor with microbes than native herbaceous species, 3) disrupts associations 
between native herbaceous species and their mycorrhizal fungi, 4) favors pathogenic microbes more closely associated with native herbaceous species than buffelgrass.

Due to a moratorium on the sale of all nitrate-containing compounds for reasons of binational security, we were unable to purchase locally or transport into Mexico nitrate fertilizer. Nitrogen was therefore added using granular $\mathrm{NH}_{4}$. Ammonium addition can cause soil acidification resulting in a loss of soil cations (Bobbink et al. 1998, Clark et al. 2007). Soil acidification can cause aluminum toxicity through cation exchange (Bobbink et al. 1998, Clark et al. 2007). Urea addition can result in increases in soil $\mathrm{pH}$ and result in toxic levels of ammonia and nitrite. There is also evidence to suggest that salts associated with granular forms of fertilizer can cause problems with cellular osmotic regulation, particularly under drought conditions (Court et al. 1964a, b).

It is generally assumed that disruptions in plant-mycorrhizal fungi interactions more negatively affect native species, which are presumably more mycorrhizal-dependent. Investigations of nitrogen addition in arid ecosystems demonstrate mixed effects on the presence and colonization of mycorrhizal fungi and the findings often depend on the plant species under investigation and background soil nutrient levels. In a study under arid conditions at the Sevilleta Long-Term Ecological Research site where nitrogen was added in granular form as $\mathrm{NH}_{4} \mathrm{NO}_{3}$ at $100-150 \mathrm{~kg} \mathrm{~N} / \mathrm{ha} / \mathrm{yr}$, Egerton-Warburton et al. (2007) found that soil relatively rich in phosphorus experienced reductions in mycorrhizal productivity, richness, and diversity under nitrogen supplementation. Where phosphorus was limiting, addition of nitrogen resulted in increased measures of AMF. In a study in semi-arid California sage scrub community, Siguenza et al. (2006) hypothesized that patterns of increased non-indigenous, annual grass invasion (Red brome, Bromus madritensis) with declines in sage brush (Artemesia californica) were driven by 
disruptions in mycorrhizal fungal associations due to atmospheric nitrogen deposition. The study confirmed that increased levels of nitrogen were negatively correlated with the presence of mycorrhizal fungi in sage brush while the fungal endophyte associated with red brome was unaffected by changes in nitrogen. Finally, in a long-term $\mathrm{CO} 2$ and nitrogen enrichment (40 kg $\mathrm{N} / \mathrm{ha} / \mathrm{yr}$ ) study in a mesic environment (Cedar Creek Ecosystem Science Reserve, Minnesota, USA) Antoninka et al. (2011) found that nitrogen addition resulted in reduced fungal spore densities.

Our procedural control for disturbance (-Bc) had no effect on the cover of buffelgrass (Fig. 2a, b) or native herbaceous species relative to controls in CD (Fig. 2c) but did have a significant negative effect on native herbaceous species in ID (Fig. 2d). In CD, nitrogen addition combined with the procedural control $(-\mathrm{Bc}+\mathrm{N})$ resulted in a significant decline in cover (Fig. 2c). This combined treatment in ID is significantly different from $\mathrm{C}$ but not $-\mathrm{Bc}$ alone (Fig. 2d). Thus, disturbance in the absence of buffelgrass removal had negative impacts on native herbaceous species, equivalent to nitrogen addition. And, when these factors were combined ($\mathrm{Bc}+\mathrm{N}$ ) there were significant negative consequences for the native herbaceous species in this system (Fig. 2c, d). Thus, treatments $+\mathrm{N},-\mathrm{B}+\mathrm{N},-\mathrm{Bc}$, and $-\mathrm{Bc}+\mathrm{N}$ similarly negatively reduced native species cover and biomass relative to $\mathrm{C}$ and $-\mathrm{B}$. We did not collect nitrogen data for any buffelgrass removal procedural controls (-Bc). We are therefore unable to assess if disturbance per se, with or without nitrogen addition $(-\mathrm{Bc}$ or $-\mathrm{Bc}+\mathrm{N})$, versus disturbance combined with decomposing buffelgrass roots (-B) acted as determinants of soil nitrogen mineralization rates. Even so, a number of mechanisms might explain these trends. If nutrient (nitrogen) release from decomposing buffelgrass root biomass operated similarly to addition of nitrogen resulting in reductions in native species biomass (through some underdetermined mechanism), then we 
would expect native species abundance in $-\mathrm{Bc}$ to be higher than any of the treatments where nitrogen was added (i.e., $+\mathrm{N},-\mathrm{B}+\mathrm{N}$, or $-\mathrm{Bc}+\mathrm{N}$ ). This is not the case; $-\mathrm{Bc}$ levels for native species are similar to the other treatments. We suggest that both the $-\mathrm{Bc}$ and $+\mathrm{N}$ treatments disrupt beneficial microbial processes resulting in lower levels of native species establishment. We further suggest that when these two treatments are combined these mechanism synergize further affecting growth of native herbaceous species.

This finding is alarming as it suggests that disturbance alone can significantly reduce native species in ID and to levels similar to high nitrogen addition. These results drive home the importance of the role of disturbance alone and in combination with nitrogen deposition in this desert ecosystem. They also highlight the need for controls for disturbances created experimentally in the process of manipulative removals (sensu Lyons and Schwartz 2001).

The main factors $-\mathrm{B}$ and $+\mathrm{N}$ had some significant effects on beginning, peak and net mineralization rates for NH4 and NO3 (Table 3 and 4; Fig. 3). Removal of buffelgrass (-B) significantly affected only NH4 at peak season in ID (Table 3) and there is no overall trend in mineralization rates with buffelgrass removal (Fig. 3). Addition of nitrogen as urea to the plots resulted in significantly higher levels of $\mathrm{NH} 4$ and NO3 across all measures in both habitats with the notable exception of a consistent non-significant effect for all measures of NO3 in ID (Table 3 and 4). There were no significant effects of the interaction term for buffelgrass removal by nitrogen on any measures of nitrogen (Table 3 and 4). These results support the findings of Ibarra-F et al. $(1995,1999)$ and suggest that higher levels of soil nutrients where buffelgrass is absent or dying are likely due to lower levels of soil resource competition. We attribute the lack of statistical significance in the nitrogen data to high variability and the number of soil replicates analyzed. 
It is important to note that rainfall for this winter rainy season was $48.2 \mathrm{~mm}$ while the average for the region is approximately $85 \mathrm{~mm}$. These data were therefore collected in a relatively low rainfall winter when the most important limiting resource was scarce. On the other hand, relative to data collected during the summer 2003, when rainfall and biomass throughout the Sonoran Desert are expected to be higher, we found herbaceous plant cover, richness, and biomass of all species to be substantially higher during the two winter months of our study (K. Lyons, unpublished data). In an average or above average rainfall year, we might expect larger effects of our buffelgrass removal and, perhaps, more positive effects of our $+\mathrm{N}$ treatment.

Differences in the effects of nitrogen addition on native herbaceous species in the two habitats suggest that the soils differ in mechanisms of nutrient cycling. Consistently significantly higher levels of $\mathrm{NH}_{4}$ in both habitat types in our $+\mathrm{N}$ plots suggest that added nitrogen went unutilized even at peak season (Table 3 ). In contrast, $\mathrm{NO}_{3}$ was consistently significantly higher only in $\mathrm{CD}$, suggesting that $\mathrm{NO}_{3}$ is more thoroughly utilized in ID than in $\mathrm{CD}$, perhaps due to higher species diversity and complementary resource use.

In the Plains of Sonora the introduction of buffelgrass has been beneficial to the ranching community; however, our study demonstrates that the introduction and spread of buffelgrass results in deterioration of the desert and thornscrub communities through competitive displacement of native herbaceous species. We also found that pollution in the form of nitrogen is likely to exacerbate this phenomenon. Both the active and passive processes of conversion of desert and thornscrub to buffelgrass grassland, combined with intensive grazing, threaten the local natural heritage and reduce the value of the region for alternative economic endeavors such as ecotourism. 


\section{Acknowledgements}

This project was funded by U.S. NSF (\#0202653) and U.S. Fulbright Commission in collaboration with the COMEXUS García-Robles Commission in Mexico. In addition, this study would not have been possible without the support of the UNAM Instituto de Ecología, Estación del Noroeste and the outstanding guidance and support of Alberto Búrquez-Montijo and Angelina Martínez-Yrizar. We owe many thanks to the numerous lab and field assistants who worked on the project, including Martha Gómez-Sapiens, Noelia de la Torre, Ramses RodríguezRamírez, Eugenio Larios-Cardenaz, Izar Said Izaguirre-Pompa, Edgar Beltrán, Alberto BúrquezMartínez, Rodrígo Rentería-Valencia, Rosalío León-Carrasco, Consuelo Orozco-Urías, Orión Norzagaray-López, Laurel Klein, and Andrea Adams. Finally, we are indebted to PATROCIPES for providing unlimited access to and use of their property for this study. The knowledge and generosity of the PATROCIPES employees Lic. Alfonso Elías-Serrano, Manual "El Che” Fontes, José Fontes, and "El Guero" Fontes were critical to this project. 


\section{Literature Cited}

Abraham, J. K., J. D. Corbin and C. M. D’Antonio. 2009. California native and exotic perennial grasses differ in their response to soil nitrogen, exotic annual grass density, and order of emergence. Plant Ecol. 201:445-456.

Aneja, V.P. and A.B. Murthy. 1994. Monitoring deposition of nitrogen-containing compounds in a high- elevation forest canopy. J Air Waste Manage 44:1109-1115.

Antoninka, A., P.B. Reich and N.C. Johnson. 2011. Seven years of carbon dioxide enrichment, nitrogen fertilization, and plant diversity influence abuscular mycorrhizal fungi in a grassland ecosystem. New Phyt. 192:200-214.

Bahre, C. 1995. Human Impacts on the Grasslands of Southeastern Arizona. Pages 230-264 in M. P. McClaran and T. R. Van Devender eds. The Desert Grassland. Tucson, Arizona: University of Arizona Press.

Baruch, Z., M. M. Ludlow and R. Davis. 1985. Photosynthetic responses of native and introduced C4 grasses from Venezuelan savannas. Oecologia 67:388-393.

Baruch, Z. and D. S. Fernandez. 1993. Water relations of native and introduced C4 grasses in a Neotropical savanna. Oecologia 96:179-185.

Baruch, Z. 1996. Ecophysiological aspects of the invasion by African grasses and their impact on biodiversity and function of neotropical savannas. Pages 79-93 in O. T. Solbrig, E. Medina, and J. F. Silva eds. Biodiversity and Savanna Ecosystem Processes: A Global Perspective. Berlin, Germany: Springer-Verlag. 
Bell, J.N.B. and M. Treshow. 2002. Air Pollution and Plant Life. Chichester, UK: J. Wiley.

Bestelmeyer, B.T. and R.L. Schooley. 1999. The ants of the southern Sonoran desert: Community structure and the role of trees. Biodiv.Cons. 8: 643-657

Binkley, D. and P. Matson. 1983. Ion exchange resin bag method for assessing forest soil nitrogen availability. Soil Sci. Soc. Am. J. 47:1050-1052.

Bobbink, R. M. Hornung and J. G. M. Roelofs. 1998. The effects of air-borne nitrogen pollutants on species diversity in natural and semi-natural European vegetation. J. Ecol. 86:717-738.

Brenner, J.C. 2011. Pasture conversion, private ranchers, and the invasive exotic buffelgrass (Pennisetum ciliare) in Mexico’s Sonoran Desert. Ann. Assoc. Am. Geogr. 101(1): 84106.

Brooks, M.L. 2003. Effects of increased soil nitrogen on the dominance of alien annual plants in the Mojave Desert. J. App. Ecol. 40: 344-353.

Bryan, K. 1925. Date of channel trenching (arroyo cutting) in the arid southwest. Science 62:338-344.

Burke, M.J.W. and J. P. Grime. 1996. An experimental study of plant community invasibility. Ecology 77(3):776-790.

Búrquez-M., A., M. E. Miller and A. Martínez-Y. 2002. Mexican grasslands, Thornscrub, and the transformation of the Sonoran Desert by invasive exotic buffelgrass (Pennisetum ciliare). Pages 126-146 in B. Tellman ed. Invasive Exotic Species in the Sonora Region. Tucson, Arizona: University of Arizona Press.

Bytnerowicz, A. and M.E. Fenn. 1996. Nitrogen deposition in California forests: A review", Env. Pollu. 92: 127-146. 
Bytnerowicz, A., P.R. Miller, D.M. Olszyk, P.J. Dawson and C.A. Fox. 1987. Gaseous and particulate air pollution in the San Gabriel Mountains of southern California. Atmos. Environ. 21: 1805-1814.

Chapin, F. S., E. S. Zavaleta, V. T. Eviner, R. L. Naylor, P. M. Vitousek, H. L. Reynolds, D. U. Hooper, S. Lavorel, O. E. Sala, S. E. Hobbie, M. C. Mack and S. Díaz. 2000. Consequences of changing diversity. Nature 405:234-242.

Christie, E. K. 1975. Physiological responses of semiarid grasses. IV Photosynthetic rates of Thyridolepis mitchelliana and Cenchrus ciliaris leaves. Aust. J. Agr. Res. 26:459-466.

Clark, C. C., E. E. Cleland, S. L. Collins, J. E. Fargione, L. Gough, K. L. Gross, S. C. Pennings, K. N., Suding and J. B. Grace. 2007. Environmental and plant community determinants of species loss following nitrogen enrichment. Ecol. Lett. 10:596-607.

Court, M.N., R.C. Stephen and J.S. Waid. 1964a. Toxicity as a cause of the inefficiency of urea as a fertilizer. I. Review. J. Soil Sci. 15:42-48.

Court, M.N., R.C. Stephen and J.S. Waid. 1964b. Toxicity as a cause of the inefficiency of urea as a fertilizer. II. Experimental. J. Soil Sci. 15:49-65.

Cox, J. R., H. L. Morton, T. N. Johnsen, G. L. Jordan, S. C. Martin, and L. C. Fierro. 1982. Vegetation restoration in the Chihuahuan and Sonoran Deserts of North America. Washington, D.C.: USDA-Agricultural Reserve Service ARM-W-28.

Cox, J. R., H. L. Morton, J. T. BaBaume and K. G. Renard. 1983. Reviving Arizona's rangelands. J. Soil Water Conserv. 38:342-345.

Cox, J.R., H.L. Morton, T.N. Johnsen, G.L. Jordan, S.C. Martin and L.C. Fierro. 1984. Vegetation restoration in the Chihuahuan and Sonoran Deserts of North America. Rangelands 6(3): 112-115. 
Cox, J. R., M. H. Martín-R., F. A. Ibarra-F., J. H. Fourie, N. F. G. Rethman and D.G. Wilcox. 1988. The influence of climate arid soil on the distribution of four African grasses. J. Range. Manage. 41:127-139.

Cox, G.W. 1999. Alien species in North America and Hawaii: impacts on natural ecosystems. Island Press, Washington, D.C.

D’Antonio, C. M. and P. M. Vitousek. 1992. Biological invasions by exotic grasses, the grass/fire cycle and global change. Annu. Rev. Ecol. Syst. 23:63-87.

DelaBarrera, E. 2008. Recent invasion of buffel grass (Cenchrus ciliaris) of a natural protected area from the southern Sonoran Desert. Rev. Mex. Biodivers. 79:385-392.

DiStefano, J. F. and J. L. Gholz. 1986. A proposed use of ion exchanges resin to measure nitrogen mineralization and nitrification in intact soil cores. Commun. Soil Sci. Plan. 17:989-998.

Draijers, G.P.J., W.P.M.F. Ivens, M.M. Bos and W. Blenten. 1989. The contribution of ammonia emissions from agriculture to the deposition of acydifying and eutrophying compounds onto forests. Environ. Pollut. 60: 55-66.

Egerton-Warburton, L.M., N.C. Johnson and E.B. Allen. 2007. Mycorrhizal community dynamics following nitrogen fertilization: A cross-site test in five grasslands. Ecol. Monogr. 77:527-544.

Esque, T.C., C.R. Schwalbe, J.A. Lissow, D.F. Haines, D. Foster and M.C. Garnet. 2006. Buffelgrass fuel loads in Saguaro National Park, Arizona, increase fire danger and threaten native species. Park Sci. 24(2):33-37. 
Eviner, V. T., F. S. Chapin, III and C. E. Vaughn. 2000. Nutrient Manipulations in Terrestrial Ecosystems. Pages 291-307 in O. E. Sala, R. B. Jackson, H. A. Mooney, and R. W. Howarth eds. Methods in Ecosystem Science. New York: Springer-Verlag.

Fenn, M.E., M.A. Poth and D.W. Johnson. 1996. Evidence for nitrogen saturation in the San Bernardino Mountains in southern California. Forest Ecol. Manag. 82: 211-230.

Flanders, A.A., W.P. Kuvlesky Jr., D.C. Ruthven III, R.E. Zaiglin, R.L. Bingham, T.E. Fulbright, F. Hernández and L.A. Brennan. 2006. Effects of invasive exotic grasses on South Texas rangeland breeding birds. Auk 123:171-182.

Franklin, K.A., K. Lyons, P.L. Nagler, D. Lampkin, E.P. Glenn, F. Molina-Freaner, T. Markow and A. Huete. 2006. Buffelgrass (Pennisetum ciliare) land conversion and productivity in the plains of Sonora, Mexico. Biol. Cons. 127:62-71.

Franklin, K. and F. Molina-Freaner. 2010. Consequences of buffelgrass pasture development for primary productivity, perennial plant richness, and vegetation structure in the drylands of Sonora, Mexico. Cons. Bio. 24:1664-1673.

Grennfeld, P. and H. Hultberg. 1986. Effects of nitrogen deposition on the acidification of terrestrial and aquatic ecosystems. Water Air Soil Pollut. 30:945-963.

Hobbs, R. J., S.L. Gulmon, V.J. Hobbs, V.J. and H.A. Mooney. 1988. Effects of fertiliser addition and subsequent gopher disturbance on a serpentine annual grassland community. Oecologia 75:291-295.

Ibarra-F., F. A., M. Martín-R., M.C. Cajal, G. Lizararga, E. Gastelum, N.M. Sau and M. Velásquez. 1987. Importancia del buffel en el aprovechamiento del pastizal nativo y recomendaciones para su establecimiento y manejo derivado de la investigación regional in IV Simposium Internacional de Ganadería. Hermosillo, Sonora, México. 
Ibarra-F., F. A., J. R. Cox and M. Martín-R. 1991. Efecto del suelo y clima en el establecimiento y persistencia del zacate buffel en México y sur de Texas. In Proceedings of the Symposium on Ecology and Revegetation of Rangelands Infested with Annual Weeds. Boise, Idaho.

Ibarra-F., F.A., J.R. Cox, M. Martin-R, T.A. Crowl and C.A. Call. 1995. Predicting buffelgrass survival across a geographical and environmental gradient. J. Range Manage. 48:53-59. Ibarra-F., F. A., J. R. Cox, M. Martín-R, T. A. Crowl, B. E. Norton, R. E. Banner and R. W. Miller. 1999. Soil physicochemical changes following buffelgrass establishment in Mexico. Arid Soil Res. Rehab. 13:39-52.

Ibarra-F., F. A., M. H. Martín-R., F. G. Denogean-B. and R. Aguirre-M. 2009. Buffelgrass, cattle, and the Sonoran Desert. Pp. in F. J. Espinosa-García, T. R. Van Devender, T. Hubbard, and B. L. Harper-Lore eds. Invasive Plants on the Move. Controlling them in North America. Tucson, Arizona: University of Arizona Press.

Hanselka, C.W. 1988. Buffelgrass - South Texas wonder grass. Rangelands 10(6): 279-281.

James, J. J., R. E. Drenovsky, T. A. Monaco and M. J. Rinella. 2011. "Managing Soil Nitrogen to Restore Annual Grass-Infested Plant Communities: Effective Strategy Or Incomplete Framework? Ecol. Appl. 21:490-502.

Johnson, D. and A. Navarro. 1992. Zacate buffel y biodiversidad en el Desierto Sonorense. In J. L. Moreno ed. Ecología, Recursos Naturales y Medio Ambiente en Sonora. Secretaria de Infraestructura Urbana y Ecología y Colegio de Sonora. Hermosillo, Sonora, México.

Kolb, A., P. Alpert, D. Enters and C. Holzapfel. 2002. Patterns of invasion within a grassland community. J. Ecol. 90:871-881. 
Lyons, K.G. and M. Schwartz. 2001. Rare species loss alters ecosistema function - invasión resitance. Ecol. Lett. 4:358-365.

MacKown, C.T., T.A. Jones, D.A. Johnson, T.A. Monaco and M.G. Redinbaugh. 2009. Nitrogen uptake by perennial and invasive annual grass seedlings: nitrogen form effects. Soil Sci. Soc. Am. J. 73:1864-1870.

McGlone, C.M., C.H. Sieg, T.E. Kolb, and T. Nietupsky. 2012. Established native perennial grasses out-compete an invasive annual grass regardless of soil water and nutrient availability. Plant Ecol. 213:445-457.

McLendon, T. and E.F. Redente. 1991. Nitrogen and phosphorus effects on secondary succession dynamics on a semi-arid sagebrush site. Ecol. 72:2016-2024.

Melgoza, G. and Nowak, R.S. 1991. Competition between cheatgrass and two native species after fire: implications from observations and measurements of root distribution. J. Range Manage. 44:27-33.

Metcalfe, S. E., D. Fowler, R. G. Derwent, M. A. Sutton, R. I. Smith and J. D. Whyatt. 1999. Spatial and temporal aspects of nitrogen deposition. Pages 15-50 in S. J. Langran, ed. The Impact of Nitrogen Deposition on Natural and Semi-natural Ecosystems. Dordrecht, The Netherlands: Kluwer Academic.

Miranda, Z. H., M. Silva-O. and F. Ramírez-M. 1999. Algunas recomendaciones en el establecimiento y manejo de praderas de zacate buffel. SAGAR- INIFAP-Fundación Produce. Hermosillo, Sonora, México.

Morales-Romero, D. and F. Molina-Freaner. 2008. Influence of buffelgrass pasture conversion on the regeneration and reproduction of the columnar cactus, Pachycereus pectenaboriginum, in northwestern Mexico. J. Arid Environ. 72:228-237. 
Norton, J.B., T.A. Monaco and U. Norton. 2007. Mediterranean annual grasses in western North America: Kids in a candy store. Plant Soil 298:1-5.

Olsson A, J. Betancourt, M. McClaran and S. Marsh. 2012. Sonoran Desert Ecosystem transformation by a C4 grass without the grass/fire cycle. Divers. Distrib. 18(1):10-21.

Peake, D.C.I., R.J.K. Myers and E.F. Henzell. 1990. Sown pasture production in relation to nitrogen fertilizer and rainfall in southern Queensland. Trop. Grasslands 24:291-298.

Rao, L.E. and E.B. Allen. 2010. Combined effects of precipitation and nitrogen deposition on native and invasive winter annual production in California deserts. Oecologia 162:10351046.

Robertson, G. P., D. C. Coleman, C. S. Bledsoe and P. Sollins. 1999. Standard Soil Methods for Long-term Ecological Research. Long-term Ecological Network Series. Oxford, Oxford University Press, England.

SAS Institute. 2004. SAS/STAT 9.1. Cary, North Carolina, U.S.A.

Sands, J. P., L.A. Brennan, F. Hernández, W.P. Kuvlesky Jr., J.F. Gallagher, J. F. and D.C. Ruthven III, et al. 2009. Impacts of buffelgrass (pennisetum ciliare) on a forb community in south texas. Invas. Plant Sci. Manage. 2(2):130-140.

Scherer-Lorenzen, M., A. Elend, S. Nollert and E. D. Schulze. 2000. Plant invasions in Germany: general aspects and impact of nitrogen deposition. Pages 351-368 in H. A. Mooney and R. J. Hobbs, eds. Invasive Species in a Changing World. Washington, DC: Island Press.

Seabloom, E.W., W.S. Harpole, O.J. Reichman and D. Tilman. 2003. Invasion, competitive dominance, and resource use by exotic and native California grassland species. P. Natl. Acad. Sci. 100:13384-13389. 
Shreve, F. and I. L. Wiggins. 1964. Vegetation and Flora of the Sonoran Desert. Stanford University Press, California.

Sigüenza, C., Crowley, D.E. and Allen, E.B. 2006. Soil microorganisms of a native shrub and exotic grasses along a nitrogen deposition gradient in southern California. Appl. Soil Ecol. 32:13-26.

Simoes, M., and Z. Baruch. 1991. Responses to simulated herbivory and water stress in two tropical C4 grasses. Oecologia 88:173-180.

Smyth, A., M. Friedel and C. O'Malley. 2009. The influence of buffel grass (Cenchrus ciliaris) on biodiversity in an arid Australian landscape. Rangeland J. 31:307-320.

Stevens, J. M. and J.S. Fehmi, J. S. 2009. Competitive effect of two nonnative grasses on a native grass in southern Arizona. Invas. Plant Sci. Manage. 2:379-385.

Tilman, D. 1997. Community invisibility, recruitment limitation, and grassland biodiversity. Ecology 78:81-92.

Tjelmeland, A.D., T.E. Fulbright and J. Lloyd-Reilley, J. 2008. Evaluation of herbicides for restoring native grasses in buffelgrass-dominated grasslands. Rest. Ecol. 16:263-269.

VanDevender, T.R., R.S. Felger, A.L. Reina-G. and J.J. Sanchez-Escalante. 2009. Sonora: Nonnative and invasive plants. Pages 85-104 in B. Tellman ed. Invasive Plant on the Move: Controlling them in North America. Tucson, University of Arizona Press.

Vasquez, E., R. Sheley and T. Svejcar. 2008. Creating invasion resistant soils via nitrogen management. Invas. Plant Sci. Manage. 1:304-314.

Wedin, D. A. and D. Tilman. 1996. Influence of nitrogen loading and species composition on the carbon balance of grasslands. Science 274:1720-1723. 
Williams, D. G. and Z. Baruch. 2000. African grass invasion in the Americas: Ecosystem consequences and the role of ecophysiology. Biol. Invas. 2:123-140.

\section{Tables}

Table 1. Buffelgrass cover responses to treatments

\begin{tabular}{|c|c|c|c|c|c|c|}
\hline \multirow{3}{*}{ source } & \multicolumn{6}{|c|}{ buffelcover } \\
\hline & \multicolumn{3}{|c|}{$\mathrm{CD}^{1}$} & \multicolumn{3}{|c|}{$\mathrm{ID}^{2}$} \\
\hline & $\mathrm{df}$ & $F$ & $\bar{p}$ & $d f$ & $\bar{F}$ & $\bar{p}$ \\
\hline Buffelgrass removal & 2 & 64.74 & 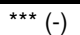 & 2 & 39.83 & $\overline{* \star \star *}(-)$ \\
\hline Nitrogen & 1 & 0.53 & 0.484 & 1 & 0.07 & 0.796 \\
\hline Buffelgrass removal*nitrogen & 2 & 0.24 & 0.789 & 2 & 1.47 & 0.262 \\
\hline Block & 2 & 11.66 & 0.002 & 3 & 0.23 & 0.874 \\
\hline Plot(removal* ${ }^{*}$ itrogen*block) & 10 & 16.41 & *** & 15 & 3.96 & *夫夫 \\
\hline
\end{tabular}


Table 2. Native herbaceous species cover, richness and biomass responses to treatments

\begin{tabular}{|c|c|c|c|c|c|c|c|c|c|c|c|c|c|c|c|c|c|c|}
\hline \multirow{3}{*}{ source } & \multicolumn{6}{|c|}{ cover } & \multicolumn{6}{|c|}{ richness } & \multicolumn{6}{|c|}{ biomass } \\
\hline & \multicolumn{3}{|c|}{$\mathrm{CD}^{1}$} & \multicolumn{3}{|c|}{$I^{2}$} & \multicolumn{3}{|c|}{$C D$} & \multicolumn{3}{|c|}{ ID } & \multicolumn{3}{|c|}{$C D$} & \multicolumn{3}{|c|}{ ID } \\
\hline & $d f$ & $\mathrm{~F}$ & $p$ & $\mathrm{df}$ & $\mathrm{F}$ & $p$ & $\mathrm{df}$ & $\mathrm{F}$ & $p$ & $\mathrm{df}$ & $\mathrm{F}$ & $p$ & $\mathrm{df}$ & $\mathrm{F}$ & $p$ & $\mathrm{df}$ & $\mathrm{F}$ & $p$ \\
\hline Buffelgrass removal & 2 & 6.18 & $0.018(+)$ & 2 & 1.72 & $0.052(+)$ & 2 & 2.81 & $0.108(+)$ & 2 & 4.13 & $0.037(+)$ & 2 & 6.20 & $0.010(+)$ & 2 & 7.81 & $0.006(+)$ \\
\hline Nitrogen & 1 & 6.14 & $0.033(-)$ & 1 & 2.74 & $0.046(-)$ & 1 & 0.28 & 0.611 & 1 & 1.16 & 0.298 & 1 & 3.29 & 0.070 & 1 & 7.15 & $0.010(-)$ \\
\hline Buffelgrass removal*nitrogen & 2 & 0.35 & 0.711 & 22 & 0.47 & 0.634 & 2 & 1.21 & 0.338 & 2 & 0.12 & 0.891 & 2 & 0.15 & 0.700 & 2 & 0.91 & 0.340 \\
\hline Block & 2 & 0.76 & 0.492 & 3 & 1.86 & 0.180 & 2 & 0.31 & 0.740 & 3 & 2.52 & 0.098 & 2 & 4.19 & 0.020 & 3 & 2.43 & 0.067 \\
\hline Plot(removal'nitrogen' & 10 & 5.48 & 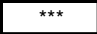 & 15 & 26.00 & 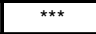 & 10 & 11.67 & $* \star \star \star$ & 15 & 8.41 & $* \star \star \star$ & 10 & 6.24 & 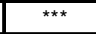 & 15 & 10.20 & $\overline{* \star \star}$ \\
\hline
\end{tabular}

$1-\mathrm{CD}=$ converted desert

2 - ID = intact desert

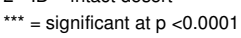


Table 3. Ammonium $\left(\mathrm{NH}_{4}\right)$ response to treatments

\begin{tabular}{|c|c|c|c|c|c|c|c|c|c|c|c|c|c|c|c|c|c|c|}
\hline \multirow{3}{*}{ source } & \multicolumn{6}{|c|}{ total available $\mathrm{NH}_{4}$ at $\mathrm{t}_{0}$} & \multicolumn{6}{|c|}{ total available $\mathrm{NH}_{4}$ at $\mathrm{t}_{\text {peak }}$} & \multicolumn{6}{|c|}{ net $\mathrm{NH}_{4}$ mineralization rate } \\
\hline & \multicolumn{3}{|c|}{$C D$} & \multicolumn{3}{|c|}{ ID } & \multicolumn{3}{|c|}{$C D$} & \multicolumn{3}{|c|}{ ID } & \multicolumn{3}{|c|}{$\mathrm{CD}$} & \multicolumn{3}{|c|}{ ID } \\
\hline & $\mathrm{df}$ & $\mathrm{F}$ & $\mathrm{p}$ & $\mathrm{df}$ & $\mathrm{F}$ & $\mathrm{p}$ & $\mathrm{df}$ & $\mathrm{F}$ & $\mathrm{p}$ & $\mathrm{df}$ & $\mathrm{F}$ & $\mathrm{p}$ & $\mathrm{df}$ & $\mathrm{F}$ & $\mathrm{p}$ & $d f$ & $\mathrm{~F}$ & $\mathrm{p}$ \\
\hline Buffelgrass removal & 1 & 0.01 & 0.974 & 1 & 1.14 & 0.294 & 1 & 0.05 & 0.829 & 1 & 4.19 & $0.05(+)$ & 1 & 3.71 & 0.069 & 1 & 0.79 & 0.382 \\
\hline Nitrogen & 1 & 81.50 & ${ }^{\star \star \star *}(+)$ & 1 & 36.72 & ${ }^{* \star \star}(+)$ & 1 & 8.55 & $0.009(+)$ & 1 & 20.36 & ${ }^{* \star *}(+)$ & 1 & 6.57 & $0.019(+)$ & 1 & 10.93 & $0.003(+)$ \\
\hline Buffelgrass removal*nitrogen & 1 & 0.00 & 0.948 & 1 & 1.10 & 0.303 & 1 & 0.02 & 0.887 & 1 & 3.77 & 0.062 & 1 & 3.36 & 0.083 & 1 & 0.90 & 0.352 \\
\hline
\end{tabular}


Table 4. Nitrate $\left(\mathrm{NO}_{3}\right)$ response to treatments

\begin{tabular}{|c|c|c|c|c|c|c|c|c|c|c|c|c|c|c|c|c|c|c|}
\hline \multirow{3}{*}{ source } & \multicolumn{6}{|c|}{ total available $\mathrm{NO}_{3}$ at $\mathrm{t}_{0}$} & \multicolumn{6}{|c|}{ total available $\mathrm{NO}_{3}$ at $\mathrm{t}_{\text {peak }}$} & \multicolumn{6}{|c|}{ net $\mathrm{NO}_{3}$ mineralization rate } \\
\hline & \multicolumn{3}{|c|}{$C D$} & \multicolumn{3}{|c|}{ ID } & \multicolumn{3}{|c|}{$C D$} & \multicolumn{3}{|c|}{ ID } & \multicolumn{3}{|c|}{$C D$} & \multicolumn{3}{|c|}{ ID } \\
\hline & \begin{tabular}{l|l}
$\mathrm{df}$ & \\
\end{tabular} & $\mathrm{F}$ & $p$ & df & $\mathrm{F}$ & $p$ & $\mathrm{df}$ & $\mathrm{F}$ & $p$ & $\mathrm{df}$ & $\mathrm{F}$ & $p$ & df & $\mathrm{F}$ & $p$ & $\mathrm{df}$ & $\mathrm{F}$ & $p$ \\
\hline Buffelgrass removal & 1 & 0.02 & 0.896 & 1 & 1.29 & 0.264 & 1 & 0.01 & 0.908 & 1 & 1.95 & 0.174 & 1 & 0.20 & 0.663 & 1 & 0.56 & 0.459 \\
\hline Nitrogen & 1 & 5.96 & $0.024(+)$ & 1 & 1.11 & 0.300 & \begin{tabular}{|l|l}
1 & $b$
\end{tabular} & 17.25 & ${ }^{* *}(+)$ & 1 & 3.75 & 0.063 & 1 & 12.18 & $0.002(+)$ & \begin{tabular}{|l|l}
1 & $b$
\end{tabular} & 2.14 & 0.155 \\
\hline${\text { Buffelgrass removal }{ }^{*} \text { nitrogen }}$ & 1 & 0.58 & 0.455 & 1 & 1.96 & 0.173 & 1 & 0.11 & 0.743 & 1 & 0.37 & 0.550 & 1 & 0.21 & 0.652 & 1 & 0.84 & 0.367 \\
\hline
\end{tabular}




\section{Figure legends}

Figure 1. Differences in percent cover of plant growth forms in converted desert (CD) and intact desert. Only control plots shown.

Figure 2. Treatment effects on buffelgrass cover $(a, b)$ and native herbaceous species cover $(c, d)$ and biomass (e, f) in converted desert (CD) and intact desert (ID). Treatment designations are as follows: $\mathrm{C}=$ control; $-\mathrm{B}=$ buffegrass removal $;+\mathrm{N}=$ nitrogen addition; $-\mathrm{B}+\mathrm{N}=$ buffelgrass removal with nitrogen addition; $-\mathrm{Bc}=$ disturbance procedural control; $-\mathrm{Bc}+\mathrm{N}=$ disturbance procedural control with nitrogen addition.

Figure 3. Treatment effects on net $\mathrm{NH}_{4}(\mathrm{a})$ and $\mathrm{NO}_{3}$ (b) mineralization rates in converted grassland (CG) and intact desert (ID). Treatment designations are as follows: $\mathrm{C}=$ control; $-\mathrm{B}=$ buffegrass removal; $+\mathrm{N}=$ nitrogen addition; $-\mathrm{B}+\mathrm{N}=$ buffelgrass removal with nitrogen addition . 